\title{
Adaptation Technology: Benefits of Hydrological Services-Watershed Management in Semi-Arid Region of India
}

\author{
Anupam Khajuria*, Sayaka Yoshikawa, Shinjiro Kanae \\ Department of Civil Engineering, Tokyo Institute of Technology, Tokyo, Japan \\ Email: ${ }^{*}$ khajuria.a.aa@m.titech.ac.jp
}

Received 30 January 2014; revised 28 February 2014; accepted 25 March 2014

Copyright (C) 2014 by authors and Scientific Research Publishing Inc.

This work is licensed under the Creative Commons Attribution International License (CC BY). http://creativecommons.org/licenses/by/4.0/

(c) (i) Open Access

\begin{abstract}
Watershed management consists of multifunctional activities to manage and address the increasing water resource problems. Ever increasing water demand and rapidly depleting water resources, it has become necessary to develop the adaptation options to recharge groundwater resources. A watershed is a special kind of Common Pool Resources (CPRs); an area is defined by hydrological linkages where optimal management requires coordinating the use of natural resources by public participation. Watershed developments have shown significant positive impacts on water table, perennially of water in wells and water availability especially in semi-arid regions. This paper describes direct and indirect impacts of the watershed activities and benefits of hydrological services dealing with watershed management with future prediction of net irrigation water supply. In the present work, we have also discussed the multiple impacts of watershed of CPRs for improving groundwater and surface water resources.
\end{abstract}

\section{Keywords}

Watershed Development, Adaptation Options, Hydrological Services, Ground Water, Common Pool Resources, India

\section{Introduction}

Climate change is projected to have significant impacts on water resources affecting agriculture. It may lead to an intensification of extreme of the global hydrological cycle and could have major impacts on both groundwater and surface water supply [1]. Groundwater resources play a major role in ensuring livelihood security across

\footnotetext{
${ }^{*}$ Corresponding author.
}

How to cite this paper: Khajuria, A., et al. (2014) Adaptation Technology: Benefits of Hydrological Services-Watershed Management in Semi-Arid Region of India. Journal of Water Resource and Protection, 6, 565-570. 
the world, especially in economies that depend on agriculture. The efficient use of water as resource conservation, environmental friendliness, appropriateness of technology, economic viability and social acceptability of development issues are major priority for agriculture in water scarce regions [2].

Adaptation refers to "adjustments in ecological, social or economic systems in response to actual or expected climatic stimuli and their effects or impacts. It refers to changes in processes, practices and structures to moderate potential damages or to benefit from opportunities associated with climate change" [3]. The possible adaptation responses to the impact of irrigation water resources include both supply and demand side [4]. Adaptation option "Watershed technology" is one of a way to raise rainfed agricultural production, conserve natural resources and increase water availability in agricultural purposes especially in the world's semi-arid and tropical regions. Watershed development is also a special case of multiple-use of Common Pool Resources (CPRs) by showing the linkages of optimize use of groundwater for conservation, agricultural productivity and benefit-cost of all users [5]. And also watershed management is a best approach to managing forestry, agriculture, pasture and water management, with an objective of sustainable management of natural resources. This article discusses the role and impact of watershed management and investigates the benefits of hydrological services of effective and properly managed watershed programme in India. In this article, we choose, discuss and determine the impacts of watershed challenge of the case study of "Gokulpura-Goverdhanpura watershed" semi-arid region of India. And also we assess the multi-faced benefits "Common Pool Resources" of watershed development.

\section{Watershed Development and Its Role and Impacts}

Watershed development is the process of organizing the use of natural resources to provide necessary goods and services to people, while mitigating the detrimental impacts of land-use activities on soil and water resources. This approach recognizes the intrinsic interrelationships among soil, water, and land use and the connections between upland watersheds and larger downstream river basins.

Watersheds provide a diversity of benefits to local inhabitants and to a greater number of people within the larger river basin through the flows of water and other natural resources off the watersheds. The components of watershed development and its role are summarized in Table 1.

The watershed development involving the entire community and natural resources influence 1) productivity and production of crops, changes in land use and cropping pattern, 2) attitude of the community and their participation, 3) socio-economic conditions such as income, employment, assets, health and education, 4) impact on environment, 5) use of land, water, human and livestock resources, 6) development of institutions for implementation and 7) ensuring sustainability of improvement. It is thus clear that watershed development is a key to sustainable production of food, fodder, and fuel wood and meaningfully addresses the social, economic and cultural status of the rural community [6] [7].

The intended impacts of watershed development are to increase groundwater recharge and increase overall water resource availability. Soil and water conservation measures, drainage-line treatments such as check-dams and tree planting are aim to reduce runoff and increase percolation. Watershed development projects may actually contribute to increased competition between water use for irrigation and domestic use, because extending

Table 1. Components of watershed developemnt and its role.

\begin{tabular}{|c|c|c|}
\hline Activity & Objective & Impact \\
\hline Check dams & $\begin{array}{l}\text { Stop/slow down } \\
\text { water runoff in gullies }\end{array}$ & $\begin{array}{l}\text { Recharge of groundwater and nearby wells. } \\
\text { Creations of open water bodies }\end{array}$ \\
\hline Ponds & $\begin{array}{l}\text { Groundwater recharge } \\
\text { water for cattle }\end{array}$ & Recharge of groundwater. Creation of big open water bodies \\
\hline Gully plugs, Gabions & $\begin{array}{l}\text { Primarily to trap sediment/silt in } \\
\text { gullies and to stabilize the guilty }\end{array}$ & $\begin{array}{l}\text { Keeps sediment out of downstream areas. Increased } \\
\text { water infiltration due to slowing down water }\end{array}$ \\
\hline Earthen loose boulders & Stabilize existing drainage system & Reduced erosion \\
\hline $\begin{array}{l}\text { Water harvesting } \\
\text { plus irrigation }\end{array}$ & $\begin{array}{l}\text { Ensure first and second crops } \\
\text { by means of irrigation. }\end{array}$ & $\begin{array}{l}\text { Considerable increase in food production. Increased biomass. } \\
\text { Creation of open water bodies. Less water down-stream in catchments }\end{array}$ \\
\hline $\begin{array}{l}\text { Contour/boundary } \\
\text { trenches/bunds }\end{array}$ & $\begin{array}{l}\text { Stop runoff and sediment } \\
\text { out of farmer's field }\end{array}$ & $\begin{array}{c}\text { Increased water availability and increased agricultural production. } \\
\text { Reduced loss of especially fertile soils }\end{array}$ \\
\hline
\end{tabular}


the irrigated area is often an explicit objective or an unintended outcome.

1) Increase in groundwater level: Various factors are accountable for increase in ground water. Land development activities such as contour bunding, land levelling and cultivation practices also contribute towards accumulation of ground water.

2) Increase in surface and stream flow: Both surface water and stream flow has increased during the post watershed development. In Rajasthan, $49 \%$ watersheds increase $<20 \%$ in surface water.

3) Soil erosion reduction: The best performing watersheds are those where soil erosion was reduced by more than 50 percent and the worst performing are the ones where there is an increase in soil erosion or the implementation failed in arresting soil erosion.

4) Runoff reduction: According to the beneficiaries this has been possible because of the contour bunding or field bunding which has also helped in checking the runoff of rainwater resulting in soil moisture retention.

5) Change in land use pattern: With increase in surface water conservation and increase in availability of water in the watershed regions, it is expected that there will be more positive change in land use pattern.

6) Cropping pattern and agricultural productivity: Both agricultural diversification and intensification lead to increase in agricultural productivity in the regions where watershed development are effective.

\section{Watershed Development in India}

Watershed management has come into focus in India with the advent of crop productivity fluctuations with the green revolution since 1980s. Watershed development is an ever-popular rural development mantra in India. The number and range of programmes continue to increase and the Government of India have invested over US\$500 million per year into the rehabilitation of watersheds. Increased emphasis on watershed development programs for dry land plain regions, inter alia, is a manifestation of the shifting priorities in the agricultural sector, which until recently concentrated mainly on crops and regions with assured irrigation [8] [9].

The direct and indirect impacts of water services in watershed interventions are summarized in Table 2. Irrigation and agriculture were boosted through watershed interventions and the irrigation water use especially arid and semi-arid regions [7] [10].

\section{Case Study of Gokulpura-Goverdhanpura Watershed Development}

Location: The study was undertaken in the Gokulpura-Goverdhanpura watershed situated in southeastern part of Rajasthan in India. The watershed is located about $40 \mathrm{Km}$ northwest of Blundi town and lies between latitude $25^{\circ} 35^{\prime} \mathrm{N}$ and longitude $75^{\circ} 25^{\prime} \mathrm{E}$. (Figure 1 ) with total area of 1355 ha. The adjoining states are Punjab and Haryana in the North, Uttar Pradesh in the Northeast, Madhya Pradesh in the Southeast, and Gujarat in the Southwest. Rajasthan is the largest State in the country in terms of area and also one with the highest proportion of land occupied by desert. It receives only 1 percent of the available water, which supports 5 per cent of population and 10 per cent of the geographical area [11]. The mean annual rainfall is $420 \mathrm{~mm}$ with extreme variation [12]. The development of the Gokulpura-Goverdhanpura watershed started in 1996. Data for the empirical study was collected from several literature of the state of Rajasthan through the International Crops Research Institute for the Semi-Arid Tropics (ICRISAT) research team. The summarized organized 20 structures of check dams have been constructed benefiting the irrigation area about 92.5 ha. The constructed structures have objec-

Table 2. Direct and Indirect impacts of water services.

\begin{tabular}{ccc}
\hline Watershed site & Direct impacts & Indirect impacts \\
\hline $\begin{array}{c}\text { Govardhanpra-Gokulpura, } \\
\text { Rajasthan }\end{array}$ & $\begin{array}{c}\text {-Pit composting to promote } \\
\text { recycle agro and domestic waste. }\end{array}$ & $\begin{array}{c}\text {-Water harvesting and recharge measures; } \\
\text { Adihali-Mylanhalli, } \\
\text { Karnataka }\end{array}$ \\
-New bore well provided for & -Improved surface water, storage and groundwater levels. \\
Karaoia-Sengur-Jamuna, & -Newly developed dug & -Network of farm ponds; \\
Uttar Pradesh & wells and tube wells. & -Improved groundwater recharge and raised water levels. \\
Kelghar-ranjanpad, & -Community bathing & -Conservation measures, \\
Maharashtra & facilities provided. & augment springs and dug wells. \\
Kharachiya-Kharahiya & -Bore well, pumps, overhead & -Benefit for groundwater sources close to stream. \\
jam, Gujarat & tank and stand pots are Provided. & groundwater levels until drought (tankers still required). \\
\hline
\end{tabular}




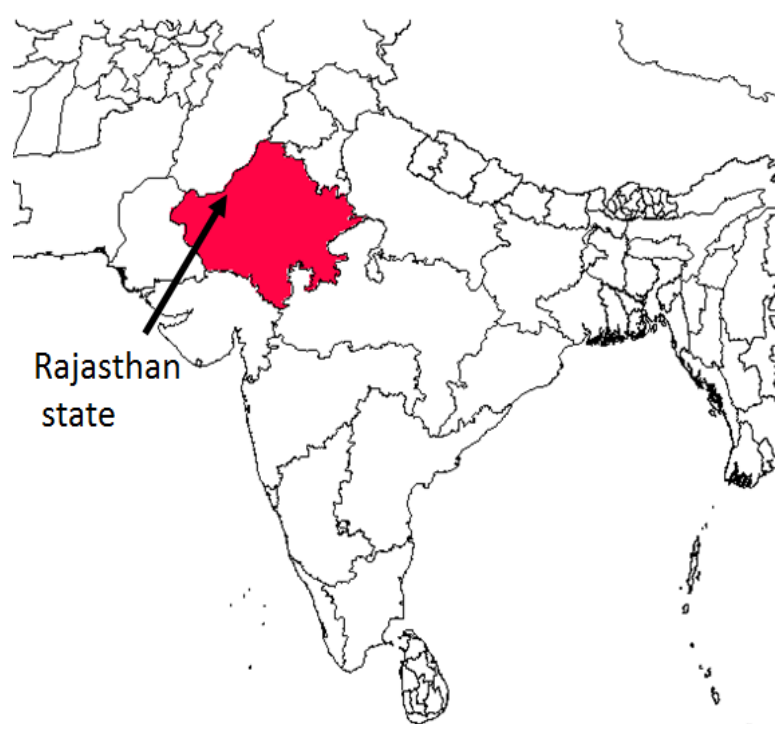

Figure 1. Location of study area Gokulpura-Goverdhanpura watershed, Rajasthan, India.

tive and impact as shown in above Table 1.

Impacts on socio-economic, technical and ecological challenges: Socio-economic challenges: The socioeconomic indicators are changes in household income, per capita income, consumption expenditure, employment, migration, people's participation and household assets at the village level were considered [13]. The results on the poverty indicators of watershed development indicate the farmers belonging to marginal and small land holding are getting more benefits. The percentage of per capita income was higher from 8\% to 24\% [12].

Technical challenges: The structures like check dams, sunken ponds help enhance the surface water storage capacity which helps in improving groundwater recharge. The major significant is increase in groundwater level in wells even during the low rainfall years [14].

Ecological challenges: The area under irrigation increased by $66 \%$ after the implementation of the watershed development. This resulted in marked reduction in crop failures and increased farmers 'confidence to invest in improved agricultural inputs [12]. In addition, about 35 ha land was brought under horticulture with irrigation facility. The annual runoff is reduced by $52 \%$ and soil loss by $64 \%$ and the land-use pattern is changing with watershed constructed structures [12] [14].

\section{Benefits of Hydrological Services}

Of the many ecosystem services that watersheds provide, hydrological services constitute some of the most economically and socially valuable [15]. These services largely fall into four broad categories: water filtration/ purification; seasonal flow regulation; erosion and sediment control and habitat preservation. The increasing vulnerability of agricultural output to variations in rainfall, particularly during droughts when the soil moisture is scarce, is attributed to inadequate expansion of irrigation. Watersheds with a high proportion of land covered by intact forests and wetlands are particularly effective at moderating runoff and purifying water supplies. The vegetation and soils of forests and wetlands in watershed varies with seasonal variation. Even the cost and benefit are distributed unevenly, which is resulting from spatial variation and multiple, conflicting uses of natural resources. The conflict between upper watershed which is using for grazing and down watershed helps to protecting for regeneration to support downstream irrigation. Deforestation, road construction, clear-cutting, and poor farming practices can send large influxes of eroded sediments into rivers and streams, markedly degrading the quality of water and of aquatic habitats [9]. Watershed development activities have significant impact on groundwater recharge, access to groundwater and the expansion in irrigated area. And also these activities have been found alter crop pattern, increase crop yields and crop diversification and enhanced employment and farm income. Watershed protection has reduced capital, operation and maintenance costs in developing countries and contributes to the natural resource conservation. 
In order to estimate the agricultural water withdrawal, we have utilized a model based on an integrated global water resource, known as the H08 model [8]. The net irrigation water from each supply source is shown in Figure 2. The river and large reservoir are continuously same trend from previous to predicted future years whereas additional water to the total water supply increases.

\section{Incentives for Common Pool Resource Management in Watershed Development}

Common pool resources (CPRs) are significant for poor people's livelihood with the diverse resources e.g. water, forest and fodder. According to Ostrom (1990) [15], "Whenever one person cannot be excluded from the benefits that others provide, each person is motivated not to contribute to the joint effort, but to free ride on the efforts of the others. If all participants choose to free ride, the collective benefit will not be produced". CPRs are the particular challenge for watershed which is commonly involved into groundwater and surface water to ensure sustainable management of natural resources [16]. In the context of watershed development, CPRs in which the right uses are commonly held in both groundwater and surface water. The watershed development experiences can largely attribute to communities that make sustainable institutional and social issues. The four categories of factors play an important role; a) Resource system characteristics, b) User group characteristics, c) Institutional arrangements, d) External environment. Common pool resources make up large areas within the watershed and their sustainable management.

\section{Lesson Learnt and Conclusions}

The benefits and future direction of watershed development are described below.

Upstream and downstream flow: As the watershed development structures generate various positive externalities, quantifying the benefits from the structures like check dams, gabion structure and gully plugs. When quantifying the benefits, the zone of influence of check dams varies from $300 \mathrm{~m}$ to $400 \mathrm{~m}$ downstream and $200 \mathrm{~m}$ to $250 \mathrm{~m}$ upstream. Similarly, the zone of influence of groundwater recharge varies from $4 \mathrm{~km}$ to $5 \mathrm{~km}$ downstream [2].

Natural and artificial recharge: The structures like check dams, gabion, gully plugs, sunken ponds and field bunds are expected to increase the groundwater recharge in the wells around 30 percent. However, the natural recharge without watershed structures is reported to be about 10 percent. Thus, the impact of watershed technology care should be taken to account for the natural and artificial recharge.

Policy implication: The study has revealed that watershed developments have significant impacts on groundwater recharge, access to groundwater and the expansion in irrigated area [17] [18]. The policy must be focus on

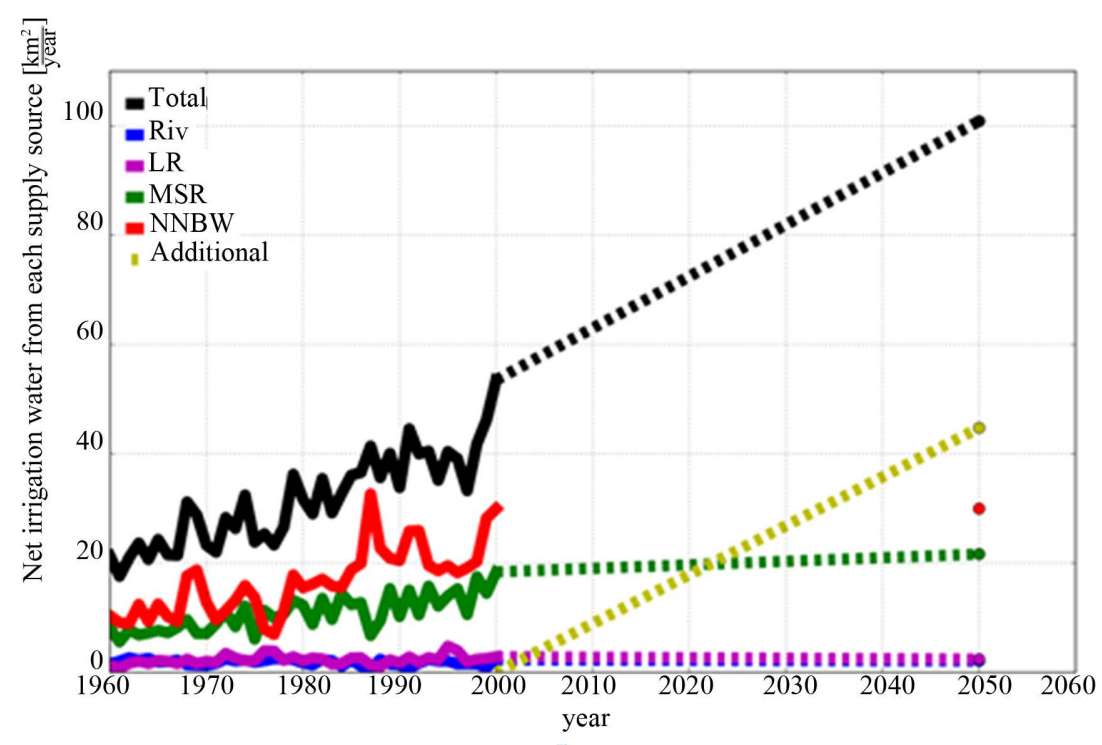

Figure 2. Net irrigation water from each source of water supply in studied area Gokulpura-Goverdhanpura watershed, Rajasthan, India. 
the development of structures which are feasible for semi-arid regions.

A coordinated effort is now required to promote watershed development and protect domestic water supplies at the same time. The watershed development projects increase the availability of groundwater at a local scale, while on the other hand, watershed programme frequently lead to greater irrigation water use for scarce water resource.

In conclusion, we have found that the watershed development is relatively feasible for the semi-arid region. There are number of options that can help to facilitate integration of adaptation technology and policy. As future tasks, we should determine deeply other adaptation options for a better and positive impact of climate change. In addition, the public and private participation may be encouraged in a big way to harvest the groundwater recharge and provide employment and farm income.

\section{References}

[1] Mimi, A.A. and Jamous, S.A. (2010) Climate Change and Agricultural Water Demand: Impacts and Adaptations. African Journal of Environmental Science and Technology, 4, 183-191.

[2] Pereira, L.S., Oweis, T. and Zairi, A. (2002) Irrigation Management under Water Scarcity. Agricultural Water Management, 57, 175-206. http://dx.doi.org/10.1016/S0378-3774(02)00075-6

[3] IPCC (2007) Climate Change 2007: Synthesis Report. Contribution of Working Groups I, II and III to the Fourth Assessment. Report of Intergovernmental Panel on Climate Change, Geneva. http://www.ipcc.ch/ipccreports/ar4-syr.html

[4] Smakhtin, V. (2004) A Pilot Global Assessment of Environmental Water Requirements and Scarcity. International Water Resources Association, 29, 307-317.

[5] Kerr, J. (2007) Watershed Management: Lessons from Common Property Theory. International Journal of the Commons, 1, 89-109.

[6] Shah, A. (1998) Watershed Development Programmes in India: Emerging Issues for Environment-Development Perspectives. Economic and Political Weekly, 33, A66-A79.

[7] Khajuria, A., Yoshikawa, S. and Kanae, S. (2013) Watershed Management: Participatory Issues for Sustainable Livelihood. The Sixth Conference of the Asia Pacific Association of Hydrology and Water Resources "Climate Change and Water Security-APHW 2013”, Seoul, 19-21 August 2013.

[8] Khajuria, A., Yoshikawa, S. and Kanae, S. (2013) Estimation and Prediction of Water Availability and Water Withdrawal in India. Annual Journal of Hydraulic Engineering, Japan Society of Civil Engineering, (SUIKO), 57, 145-150.

[9] Badal, P.S., Kumar, P. and Bisaria, G. (2006) Dimensions and Determinants of People’s Participation in Watershed Development Programmes in Rajasthan. Agricultural Economics Research Review, 19, 57-69.

[10] Prabhakar, P., Chourasia, A.K., Wani, S.P. and Sudi, R. (2013) Multiple Impact of Integrated Watershed Management in Low Rainfall Semi-Arid Region: A Case Study from Eastern Rajasthan, India. Journal of Water Resource and Protection, 5, 27-36. http://dx.doi.org/10.4236/jwarp.2013.51004

[11] Sharma, R.J.P., Singh, P. and Padaria, R.N. (2011) Social Processes and People’s Participation in Watershed Development. Journal of Community Mobilization and Sustainable Development, 6, 168-173.

[12] Pathak, P., Chourasi, A.K., Wani, A.P. and Sudi, R. (2013) Multiple Impact of Integrated Watershed Management in Low Rainfall Semi-Arid Region: A Case Study from Eastern Rajasthan, India. Journal of Water Resource and Protection (JWARP), 5, 27-36. http://dx.doi.org/10.4236/jwarp.2013.51004

[13] Deshpande, R.S. and Rajasekaran, N. (1997) Impact of Watershed Development Programme: Experiences and Issus. Artha Vijnana, 39, 374-390.

[14] Pathak, P., Wani, S.P., Sudi, R., Chourasia, A.K., Singh, S.N. and Rao, K. (2007) Rural Prosperity through Integrated Watershed Management: A Case Study of Gokulpura-Goverdhanpura in Eastern Rajasthan. Global Theme on Agroecosystems Report no. 36. Patancheru 502 324, Andhra Pradesh, India: International Crops Research Institute for the Semi-Arid Tropics (ICRISAT), 52, 1-52.

[15] Raju, Sharma, J.P., Singh, P. and Padaria, R.N. (2011) Social Processes and People’s Participation in Watershed Development. Journal of Community Mobilization and Sustainable Development, 6, 168-173.

[16] Ostrom, E. (1990) Governing the Commons: The Evolution of Institutions for Collective Action. Cambridge University Press, New York. http://dx.doi.org/10.1017/CBO9780511807763

[17] World Bank (2007) Watershed Management Approaches, Policies and Operations: Lessons for Scaling-Up. Agriculture and Rural Development Department, World Bank, Washington DC.

[18] Swami, V.A. and Kulkarni, S.S. (2011) Watershed Management-A Means of Sustainable Development-A Case Study. International Journal of Environmental Science and Technology (IJEST), 3, 2105-2112. 